\title{
Correlation of cord bilirubin levels with hyperbilirubinaemia in ABO incompatibility
}

\author{
H. M. RISEMBERG, E. MAZZI, M. G. MACDONALD, M. PERALTA, AND \\ FREDERICK HELDRICH
}

From the Capital Regional Neonatal Intensive Care Unit, Albany, New York; the Division of Neonatology, Baltimore City Hospitals; and Departments of Pediatrics, Johns Hopkins University and St. Agnes Hospital, Baltimore, Maryland, USA

SUMMARY We studied 91 offspring of ABO incompatible pregnancies and 30 controls resulting from O-O pregnancies to test whether cord bilirubin levels could be used to predict the severity of hyperbilirubinaemia in ABO incompatibility. Blood group, direct Coombs's test, and serum bilirubin estimations were carried out on cord blood, and bilirubin estimations at 12, 24, 36, and 48 hours of life.

All newborns in whom the cord bilirubin was greater than $4 \mathrm{mg} / 100 \mathrm{ml}(68 \mu \mathrm{mol} / \mathrm{l})$ developed severe hyperbilirubinaemia (levels $>16 \mathrm{mg} / 100 \mathrm{ml}(273 \mu \mathrm{mol} / \mathrm{l})$ at $12-36$ hours) and required exchange transfusion. It is concluded that in ABO incompatibility infants with cord bilirubin level greater than $4 \mathrm{mg} / 100 \mathrm{ml}$ represent a special 'high risk' category and should be placed in a centre where frequent re-evaluation and appropriate therapy are available.

This study was designed to test the reliability of cord bilirubin levels in predicting the severity of hyperbilirubinaemia in ABO incompatibility. Recent evidence that bilirubin levels much lower than 20 $\mathrm{mg} / 100 \mathrm{ml}(342 \mu \mathrm{mol} / \mathrm{l})$ may cause damage to the central nervous system, particularly when they are associated with other pathological conditions, has underlined the need for such a study (Stern and Denton, 1965; Boggs et al., 1967; Gartner et al., 1970.

Heterospecificity of mother and child with respect to the blood groups, $\mathrm{A}, \mathrm{B}$, and $\mathrm{O}$ is common. The incidence depends upon the gene incidence for $A B O$ in a given population and has been estimated at between 20 and $25 \%$ of all pregnancies (Zeulzer and Kaplan, 1953). ABO haemolytic disease will manifest itself in less than $10 \%$ of these cases, and will almost exclusively occur in $\mathrm{A}-$ and $\mathrm{B}-$ babies of group $\mathrm{O}$ mothers. These babies are at a potentially higher risk of severe hyperbilirubinaemia, but criteria for early recognition of severe disease have been slow in forthcoming. All methods of therapy for hyperbilirubinaemia present potential hazards, and if they are to be used early in the course of the disease the 'at risk' group must be defined.

Received June 28, 1976
Since Allen and Diamond published their wellknown treatise on $R h$ isoimmunization in 1958 it has been recognized that the level of cord bilirubin is of considerable value in predicting the severity of subsequent haemolysis. Because of the relative infrequency of severe $\mathrm{ABO}$ disease, the urgency for predictive criteria in this disease has not seemed great, and there has been a tendency to presume that the criteria for $\mathrm{Rh}$ disease could be applied to $\mathrm{ABO}$ incompatibility. A large number of neonates are being admitted to our intensive care units with jaundice secondary to $\mathrm{ABO}$ incompatibility, who already have dangerously high levels of bilirubin at the time of admission. Criteria for early recognition of infants at high risk of hyperbilirubinaemia would encourage earlier transfer of these infants for appropriate therapy.

There are several features of $\mathrm{ABO}$ incompatibility that suggest to us that the predictive criteria used in $\mathrm{Rh}$ isoimmunity cannot be assumed to apply. (1) Hyperbilirubinaemia, when it occurs, is rarely associated with significant anaemia (Rosenfield, 1955). (2) Anti-A and anti-B antibodies are normally present in the maternal serum, and normally reach the fetus (Zeulzer and Kaplan, 1953; Rosenfield, 1955). (3) In heterospecific pregnancies the maternal antibody patterns during the period of gestation show no more response than those of the homo- 
specific group, up to the time of delivery. Changes in levels of antibody occur only after delivery in the heterospecific group (Zeulzer and Kaplan, 1953). (4) There is no cumulative effect on serum antibody levels, or on the fetus, in subsequent heterospecific pregnancies, in a manner comparable to the progression of $\mathrm{Rh}$ incompatibility. (5) Though a positive Coombs's test is more often found in those babies with moderate and severe hyperbilirubinaemia, the reaction is often weak and there is an unacceptably high number of 'false negative' results (Rosenfield, 1955).

Despite the failure to detect a prenatal increase in maternal antibody levels there is no doubt that intrauterine haemolysis must take place in this disease, and cord blood bilirubin levels are often considerably raised. This study was designed to investigate the bilirubin levels in heterospecific pregnancies, involving group $\mathrm{O}$-mothers and $\mathrm{A}-$ or B-babies, and to determine whether these levels offer a reliable means of predicting the severity of subsequent hyperbilirubinaemia.

For the purpose of this study we have used the following terminology. ABO incompatibility without significant hyperbilirubinaemia refers to infants with serum bilirubin levels $<10 \mathrm{mg} / 100 \mathrm{ml}(171 \mu \mathrm{mol} / \mathrm{l})$ at 36 hours of age. ABO incompatibility with moderate hyperbilirubinaemia refers to infants with serum bilirubin levels from 10 to $16 \mathrm{mg} / 100 \mathrm{ml}(171-273$ $\mu \mathrm{mol} / \mathrm{l})$ at 36 hours of age. ABO incompatibility with severe hyperbilirubinaemia, refers to infants with serum bilirubin levels $>16 \mathrm{mg} / 100 \mathrm{ml}(>273$ $\mu \mathrm{mol} / \mathrm{l}$ ) at $12-36$ hours of age.

\section{Methods and material}

91 term newborns of heterospecific pregnancies were studied and 30 term infants of homospecific pregnancies were used as controls. The study was prospective and involved consecutive births, except in 6 cases which were transferred from hospitals affiliated to the Maryland Regional Neonatal
Program. All of these 6 patients fell into the group with severe hyperbilirubinaemia. 10 of the 30 control infants were born consecutively at St. Agnes Hospital and 20 at Baltimore City Hospitals.

Cord blood was obtained from all newborns with group $\mathbf{O}$ mothers. When necessary the sample was kept overnight in a refrigerator, protected from light ( $\max 8 \mathrm{~h}$ ). The bilirubin level, blood group, and direct Coombs's test were carried out on each sample. Minor blood group incompatibility was ruled out in every baby with a positive Coombs's test. $R h$ incompatible babies were excluded from the study. In those cases where the newborn was found to have a blood group other than $\mathbf{O}$, bilirubin estimations were carried out at 12,24,36, and 48 hours. Bilirubin levels were estimated using a modification of the diazo reaction of Malloy and Evelyn (1937). This method was also used by the referring hospitals.

None of the infants in the study received phototherapy, and the criteria for exchange transfusion were those in currently accepted use (Klaus and Fanaroff, 1973). Informed consent was obtained before including each infant in the study.

\section{Results}

Cord bilirubin level and severity of hyperbilirubinaemia (Table 1). Of the 91 patients included in the study, $13(14 \%)$ developed severe hyperbilirubinaemia (serum bilirubin level $>16 \mathrm{mg} / 100 \mathrm{ml}(>273$ $\mu \mathrm{mol} / \mathrm{l})$ at 12-36 hours of life) and, with the exception of one patient (cord bilirubin level of $3 \cdot 5$ $\mathrm{mg} / 100 \mathrm{ml} ; 60 \mu \mathrm{mol} / \mathrm{l})$ cord bilirubin levels were $>4 \mathrm{mg} / 100 \mathrm{ml}(>68 \mu \mathrm{mol} / \mathrm{l})$ in all cases. All of these babies required exchange transfusion.

Fifteen $(17 \%)$ of the infants developed moderate hyperbilirubinaemia (serum bilirubin level between 10 and $16 \mathrm{mg} / 100 \mathrm{ml}(171-273 \mu \mathrm{mol} / \mathrm{l})$ at 36 hours of life). In all these babies the cord bilirubin level was $<4 \mathrm{mg} / 100 \mathrm{ml}$, and none required exchange transfusion. $63(69 \%)$ did not develop significant hyperbilirubinaemia (serum bilirubin level $<10$

Table 1 Correlation between cord bilirubin levels and severity of hyperbilirubinaemia at 36 hours, positive Coombs's test, and need for exchange transfusion

\begin{tabular}{|c|c|c|c|c|}
\hline & \multicolumn{4}{|c|}{ Hyperbilirubinaemia at 36 hours of age $(\mathrm{mg} / 100 \mathrm{ml} ; \mu \mathrm{mol} / \mathrm{l})$} \\
\hline & $\begin{array}{l}\text { Insignificant } \\
<10(<171)\end{array}$ & $\begin{array}{l}\text { Moderate } \\
10-16(171-273)\end{array}$ & $\begin{array}{l}\text { Severe } \\
>16(>273)\end{array}$ & Total \\
\hline \multicolumn{5}{|l|}{ Cord bilirubin } \\
\hline $\begin{array}{l}<4 \mathrm{mg} / 100 \mathrm{ml} \\
(<68 \mu \mathrm{mol} / 1)\end{array}$ & 63 & 15 & 1 & 79 \\
\hline $\begin{array}{l}>4 \mathrm{mg} / 100 \mathrm{ml} \\
(>68 \mu \mathrm{mol} / \mathrm{l})\end{array}$ & 0 & $\mathbf{0}$ & 12 & 12 \\
\hline Total & 63 & 15 & 13 & 91 \\
\hline Coombs's test positive & 10 & 9 & 12 & 31 \\
\hline Exchange transfusion & 0 & 0 & 13 & 13 \\
\hline
\end{tabular}


$\mathrm{mg} / 100 \mathrm{ml}(<171 \mu \mathrm{mol})$ at 36 hours of life). In all of these babies the cord bilirubin level was $<4$ $\mathrm{mg} / 100 \mathrm{ml}(<68 \mu \mathrm{mol})$.

Serum bilirubin levels at age 12 hours, and 24 hours and severity of hyperbilirubinaemia (Tables 2 and 3). As expected, the serum bilirubin levels at 12 hours and 24 hours of age correlated to some degree with subsequent hyperbilirubinaemia (Tables 2, 3). Of a total of 91 infants, $78(86 \%)$ developed insignificant to moderately severe hyperbilirubinaemia by the age of 36 hours (serum bilirubin $<16$ $\mathrm{mg} / 100 \mathrm{ml} ;<273 \mu \mathrm{mol} / \mathrm{l})$. In these infants the serum bilirubin level at 12 hours did not exceed $10 \mathrm{mg} / 100$ $\mathrm{ml}(171 \mu \mathrm{mol})$, and none required exchange transfusion. The remaining $13(14 \%)$ infants developed severe hyperbilirubinaemia (bilirubin level $>16$ $\mathrm{mg} / 100 \mathrm{ml}$ at $12-36$ hours of life). Serum bilirubin at 12 hours of life was $>10 \mathrm{mg} / 100 \mathrm{ml}$ in all of these infants, and all required exchange transfusion.

The 13 infants who developed severe hyperbilirubinaemia all showed a serum bilirubin level greater than $15 \mathrm{mg} / 100 \mathrm{ml}(257 \mu \mathrm{mol} / \mathrm{l})$ at 24 hours of life.

Coombs's test and severity of hyperbilirubinaemia (Table 1). Of the group with severe hyperbilirubinaemia, all but $1(0 \cdot 8 \%)$ had a positive Coombs's test.
In the moderately affected group out of a total of 15 infants, $9(60 \%)$ were Coombs's positive and 6 (40\%) Coombs's negative. Of the 63 newborns who did not develop significant hyperbilirubinaemia, 10 $(15 \%)$ were Coombs's positive and $53(85 \%)$ Coombs's negative.

Controls. The 30 patients selected as controls were blood group $\mathbf{O}$ and $\mathrm{Rh}$ compatible with their mothers. Coombs's tests were negative, and cord

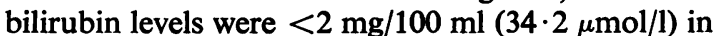
all cases. None of these infants developed significant jaundice.

\section{Discussion}

Johnstone (1953) showed that the mean cord bilirubin levels are higher in heterospecific than in homospecific pregnancies. Zuelzer and Cohen (1957) pointed out the importance of early diagnosis in ABO disease, and Robinson et al. (1960) reported that cord bilirubin levels above $3 \mathrm{mg} / 100 \mathrm{ml}(51 \cdot 3$ $\mu \mathrm{mol} / \mathrm{l})$ were highly suggestive of ABO disease. However, the literature does not provide any criteria specific for ABO disease which would allow us to predict immediately after birth which infants were likely to require therapeutic intervention because of severe hyperbilirubinaemia.

Table 2 Correlation between serum bilirubin levels at 12 hours of age and severity of hyperbilirubinaemia at 36 hours

\begin{tabular}{|c|c|c|c|c|}
\hline & \multicolumn{4}{|c|}{ Hyperbilirubinaemia at 36 hours of age $(\mathrm{mg} / 100 \mathrm{ml} ; \mu \mathrm{mol} / \mathrm{l})$} \\
\hline & $\begin{array}{l}\text { Insignificant } \\
<10(<171)\end{array}$ & $\begin{array}{l}\text { Moderate } \\
10-16(171-273)\end{array}$ & $\begin{array}{l}\text { Severe } \\
>16(>273)\end{array}$ & Total \\
\hline $\begin{array}{l}\text { Serum bilirubin } \\
\text { at } 12 \mathrm{~h} \text { of age } \\
<10 \mathrm{mg} / 100 \mathrm{ml} \\
(<171 \mu \mathrm{mol} / \mathrm{l})\end{array}$ & $\begin{array}{l}63 \\
\text { (range } 1 \cdot 0-8 \cdot 6) \\
(171-147)\end{array}$ & $\begin{array}{l}15 \\
\text { (range 6.7-9.2) } \\
(115-157)\end{array}$ & 0 & 78 \\
\hline $\begin{array}{l}\text { Total } \\
\text { Exchange transfusion }\end{array}$ & $\begin{array}{r}63 \\
0\end{array}$ & $\begin{array}{r}15 \\
0\end{array}$ & $\begin{array}{l}13 \\
13\end{array}$ & $\begin{array}{l}91 \\
13\end{array}$ \\
\hline
\end{tabular}

Table 3 Correlation between serum bilirubin levels at age 24 hours and severity of hyperbilirubinaemia at 36 hours

Hyperbilirubinaemia at 36 hours of age $(\mathrm{mg} / 100 \mathrm{ml} ; \mu \mathrm{mol} / \mathrm{l})$

\begin{tabular}{llll}
\hline Insignificant & Moderate & Severe & Total
\end{tabular}

Serum bilirubin at $24 \mathrm{~h}$ of age $<15 \mathrm{mg} / 100 \mathrm{ml}$ $(<257 \mu \mathrm{mol} / \mathrm{l})$

Serum bilirubin at $24 \mathrm{~h}$ of age $>15 \mathrm{mg} / 100 \mathrm{ml}$ $(>257 \mu \mathrm{mol} / \mathrm{l})$ $10-16(171-273) \quad>16(>273)$

Total $<10(<171)$

15 63 (31-188)

0

63

0 (range 7-12:7) (120-217)

15
0
0

78

13

(range 15.5-34.5)

(265-590)

13 
In this study all newborns in which the cord bilirubin level exceeded $4 \mathrm{mg} / 100 \mathrm{ml}(68 \mu \mathrm{mol})$ developed severe hyperbilirubinaemia (levels $>16$ $\mathrm{mg} / 100 \mathrm{ml}(>2 \cdot 73 \mu \mathrm{mol} / \mathrm{l})$ at $12-36$ hours of age). Only one infant, out of a total of 79 infants with cord bilirubin levels less than $4 \mathrm{mg}$, developed severe jaundice (see Tables 1 and 2). Newborns of heterospecific pregnancies, with cord bilirubin levels greater than $4 \mathrm{mg}$ should therefore be placed in a special 'high risk' category.

It is well known that the methods of bilirubin estimation currently in use are all somewhat inaccurate. However, the predictive criteria laid down by Allen and Diamond (1958) for Rh incompatibility rely upon these same methods of bilirubin estimation and have nevertheless served as a valuable therapeutic aid. Approximately, $50 \%$ of our patients were referred from outlying hospitals, where cord bilirubin levels had already been measured before transfer. The level of $4 \mathrm{mg} / 100 \mathrm{ml}$ for cord bilirubin level gave a reliable prediction of the severity of subsequent hyperbilirubinaemia, despite the number of different laboratories carrying out the bilirubin estimations.

The serum bilirubin levels measured at 12 and 24 hours of life also correlated with subsequent hyperbilirubinaemia (see Tables 2 and 3). We cannot, however, recommend the use of these levels as predictive criteria. At 12 hours of life 2 infants already had dangerously raised serum bilirubin levels (27 $\mathrm{mg} / 100 \mathrm{ml} ; 462 \mu \mathrm{mol} / \mathrm{l}$ ) and a further 5 infants had serum bilirubin values greater than $15 \mathrm{mg} / 100 \mathrm{ml}$ (257 $\mu \mathrm{mol} / \mathrm{l})$. All of these infants required exchange transfusion.

As previously noted by others (Rosenfield, 1955; Orzalezi et al., 1973), we found that the presence of hyperbilirubinaemia in $\mathrm{ABO}$ incompatibility is significantly associated with a positive Coombs's test (see Table 1). However, as our figures show, the direct Coombs's test is not by itself a reliable method of predicting the severity of hyperbilirubinaemia.

\section{Implications}

Our data show that the risk to infants with $\mathrm{ABO}$ incompatibility and cord bilirubin levels greater than $4 \mathrm{mg} / 100 \mathrm{ml}(68 \mu \mathrm{mol} / \mathrm{l})$ is so consistent that frequent re-evaluation is mandatory in this group, and there may be an indication for therapeutic intervention even earlier in the course of the disease than is currently the practice. This last consideration is especially important in light of recent reports that phototherapy can alter the course of haemolytic disease in newborns (Reid et al., 1972; Moller and Ebbesen, 1975), and deserves further study.

All hospitals caring for neonates should have the facilities to carry out bilirubin estimation on the cord blood. We suggest that cord blood be sent for this estimation in all infants of group $\mathbf{O}$ mothers. If the cord bilirubin level is $4 \mathrm{mg} / 100 \mathrm{ml}$ or greater, blood grouping and Coombs's testing should also be performed, without waiting for the onset of clinical jaundice. In the case of infants born in outlying hospitals, without adequate facilities for constant re-evaluation and therapy, a cord bilirubin value of $4 \mathrm{mg} / 100 \mathrm{ml}(68 \mu \mathrm{mol} / \mathrm{l})$ or greater is a strong indication for early transfer to a neonatal centre.

\section{References}

Allen, F. H., and Diamond, L. K. (1958). Erythroblastosis Fetalis. Little, Brown, Boston.

Boggs, T. R., Hardy, J. B., and Frazier, T. M. (1967). Correlation of neonatal serum total bilirubin concentrations and developmental status at eight months. Journal of Pediatrics, 71, 553-560.

Gartner, L. M., Snyder, R. N., Chabon, R. S., and Bernstein, J. (1970). Kernicterus: high incidence in premature infants with low serum bilirubin concentrations. Pediatrics, 45, 906-917.

Johnstone, J. M. (1953). Bilirubin values of cord blood in heterospecific pregnancy. Journal of Clinical Pathology, 6, 215-218.

Klaus, M. H., and Fanaroff, A. (1973). Care of the HighRisk Neonate, p. 192. Saunders, Philadelphia.

Malloy, H. T., and Evelyn, K. A. (1937). The determination of bilirubin with the photoelectric colorimeter. Journal of Biological Chemistry, 119, 481-490.

Moller, J., and Ebbesen, F. (1975). Phototherapy in newborn infants with severe rhesus hemolytic disease. Journal of Pediatrics, 86, 135-137.

Orzalezi, M., Gloria, F., Lucarelli, P., and Bottini, E. (1973). ABO system incompatibility: relationship between direct Coombs test positivity and neonatal jaundice. Pediatrics, 51, 288-289.

Reid, M. McC., Marks, E., McClure, G., and Elwood, J. H. (1972). Phototherapy in $\mathrm{Rh}$ haemolytic disease. Lancet, 1, 879-880.

Robinson, G. C., Dunn, H. G., and Wong, L. C. (1960). Clinical and laboratory findings in heterospecific pregnancy, with a note on the incidence of ABO hemolytic disease. Acta Paediatrica, 49, Suppl. 120, 53-62.

Rosenfield, R. E. (1955). A-B hemolytic disease of the newborn. Analysis of 1480 cord blood specimens, with special reference to the direct antiglobulin test and to the group $O$ mother. Blood, 10, 17-28.

Stern, L., and Denton, R. L. (1965). Kernicterus in small premature infants. Pediatrics, 35, 483-485.

Zuelzer, W. W., and Cohen, F. (1957). ABO hemolytic disease and heterospecific pregnancy. Pediatric Clinics of North America, 4, 405-428.

Zuelzer, W. W., and Kaplan, E. (1953). ABO heterospecific pregnancy and hemolytic disease. A study of normal and pathologic variants. I. Patterns of maternal $A$ and $B$ isoantibodies in unselected pregnancies. II. Patterns of $\mathbf{A}$ and $B$ isoantibodies in the cord blood of normal infants. American Journal of Diseases of Children, 88, 158-178; 179-192.

Correspondence to Dr. H. Risemberg, Capital Regional Neonatal Intensive Care Unit, Albany, New York 12208, USA. 